\title{
Priority-Driven Budgeting Policy and Regional Inequality: Does Economic Structure Transformation Really Perform as Intervening Variable?
}

\author{
Abdiyanto $^{1}$ and Ari Warokka ${ }^{2}$ \\ ${ }^{1}$ North Sumatera University, USU \\ ${ }^{2}$ Centro Internacional “Carlos V”, Universidad Autonoma de Madrid, Spain
}

Correspondence should be addressed to: Ari Warokka; ari.warokka@gmail.com;

Received date: 10 April 2014; Accepted date: 8 January 2015; Published date: 4 June 2015

Academic Editor: Cicea Claudiu

Copyright $($ 2015. Abdiyanto and Ari Warokka. Distributed under Creative Commons CC-BY 4.0

\begin{abstract}
One of the main challenges faced by local governments in developing countries is to allocate scarce resources effectively to achieve the community's highest priorities. This challenge relates to government's effort to reduce regional inequality. This paper examined the relationship between priority-based budgeting policy and local growth imbalance by using economic structure transformation as the intervening variable. The researchers employed multivariate regression and path-analysis to examine the relationship. The results revealed that the priority-based budgeting affected local inequality significantly through structural transformation. It explicitly demonstrates that the prioritized government allocation in education, health, and education plays an important role to strengthen economic transformation leading to reduce regional divergence.
\end{abstract}

Keywords: priority budget policy, regional inequality, economic structure transformation, economic growth

\section{Introduction}

In public sector management, there are two goals that public spending is supposed to strive towards, i.e. equity, which is understood as equitable distribution of economic wealth, and efficiency, which is perceived as rectifying potential market failures (Van de Walle, 1995). Those goals become a main struggle for local governments to develop meaningful and fiscally prudent budgets, as they continue to face unknown financial and political pressures. Through priority-based budgeting, local governments can achieve a fiscal health and wellness in which they assess their "picture of fiscal health" and objectively determine how to match available resources with community priorities.

Priority-based budgeting, which is similar to results-oriented (or 'performance' or 'output') budgeting (Roberts, 2003), is a 
response to poor economic conditions. It focuses on the three key components: the final outcome, the mix of strategies needed to reach it, and the activities actually undertaken to achieve the outcome. Priority-based budgeting, in contrast to incremental budgeting, where resource allocation is determined based on marginal shifts in costs, fixes the amount of governmental resources and then allocates resources across the various programs. The programs receive their allocation based on their priority. The priorities may include safe and secure communities, health, education, and community development among others. Outcome assessment then determines the efficacy of the programs. The outcome is generally a larger policy objective, an objective which the spending agencies bind themselves to achieve within the agreed confines of time and budget.

Effective resource allocation to health, education, and other social services is crucial for achieving equitable and sustainable development in a competitive environment (World Bank 2003). For advanced economy countries, this issue is relatively well-handled. Meanwhile, for emerging economies, it could be a serious challenge (OECD, 1995). Therefore, it is important to take a close look at developing countries' expenditure composition in recent years in order to test whether current public spending policies are in line with the nation's new strategy of growth with equity (Norton, 2002).

World Bank (2008) reported two phenomenons were threatening the implementation of the decentralization process in Indonesia, i.e. the similarity of public spending across regions without considering the different problems of each region and the increasing public spending corruption. The first phenomenon reflected a budgeting planning problem, meanwhile the second one revealed the effectiveness and efficiency problem in providing public goods. In the other words, the deviation of local government budget usage both administratively and spending marked up, has finally resulted in unachieved output target that had been planned or even achieved, but sacrificing more costly in the process. The World Bank report was supported by the work of Akin, Hutchinson, and Strumpf (2005), which found that inappropriate-decentralized budget policy gave negative impact on the health care provision in Uganda. Thornton (2006) supported the finding in which his study revealed the failure of proper decentralized-budget in accelerating economic growth in OECD countries.

In the context of local autonomy, the budget is governments' most important economic policy tool to alleviate regional inequality through economic growth or transformation. Public budgets translate a government's policies, political commitments, and goals into decisions on how much revenue to raise and allocate in meeting the country's competing needs, from bolstering security to improving health care to alleviating poverty (Holmes \& Evans, 2003). It underlines the fact that economic transformation requires financial resources. However, a well-designed budgetary resource's planning is a prerequisite. Recently, many emerging countries have developed the prioritybased budgeting. It is a way for local governments to spend within their means by continuously focusing on the results most relevant to their communities and the programs that influence those results to the highest possible degree (Alonso, Judge \& Klugman, 2006). In this new approach, the process involves a systematic review of existing services. It includes an analysis of why the services exist, what value they offer to citizens, how they benefit the community, what they cost, and what objectives and citizen demands they are achieving. Each service or program is assigned a score based on its contribution to desired results so that tax dollars can be allocated to those with the greatest impact (Leruth \& Paul, 2006).

Based on this fact, in this study, the researchers would like to examine the effect of priority-based budgeting on economic structure transformation and regional inequality. Our study will provide some important contributions, such as a testing of the impact of budgeting policy on a transforming region, a shift-share 
analysis on the impacted economic sectors, and a clustering analysis of the economic transformation-regional inequality relationship matrix. It will also expand the implementation of budgeting policy as the local government tool to manage the economic development. In this study, we will test specifically the intervening effect of economic transformation in the relationship between priority-based budgeting and regional inequality. It will attempt to review whether or not the prioritization of infrastructure projects of government is coherent with the developmental needs of the regions and provinces. The expected empirical findings from this study will be valuable information to set and up-date the local government policy options on alleviating poverty and accelerating economic growth.

To present the empirical findings, the paper is organized as follows. The literature review and prior studies on priority-based budgeting, economic structure transformation and regional inequality are briefly outlined in Section 2 . The methodology and research model is described in Section 3, followed by the research results and discussion in Section 4. We provide some concluding remarks in Section 5.

\section{Literature Review}

Learning from the emerging countries' experiences in implementing decentralized governance, autonomous local development also leads to a great deal of regional inequality, particularly because of differences in prior resource endowments and institutions (Bardhan, 1998). Moreover, like in Peru, it happens when local government mismanages its financial resources and sets inappropriate priorities in its budgeting policies (Ahmad \& GarcíaEscribano, 2008; Alvarado \& Morón, 2008). Meanwhile, successful economic transformation depends on a good match between prioritized programs and resource allocation (OECD, 2012). In the other words, the way, which public expenditures are allocated, plays an important role on both economic growth and the alleviation of poverty and regional inequality. There are, theoretically, three schools of thought existed on the effectiveness of investment in infrastructure as a poverty reduction strategy. The first school argues that investment in social infrastructure, which embraces investment in education and health, is more relevant to the goal of poverty reduction than physical infrastructure (Jahan \& McCleery 2005; Jerome \& Ariyo 2004). The second school maintains that investments in both physical and social infrastructure reduce poverty and regional inequality. The last school holds that investment in infrastructure in general has no effect on poverty reduction (Ogun, 2010). Referring to those prior studies, it provides an indication of a strong relationship between public budgeting, the change within the structure of an economy over time, and local disparity. Therefore, the following sections will discuss those variables' nexus and its hypothesis' development.

\section{Priority-Driven Budgeting Policy}

In the context of the economies in transition, the traditional approach to governmental budgeting, which is incremental, finally does not work properly due to the dynamic change of global economy. This gradual approach is workable, if suboptimal, in periods of reasonably stable expenditure and revenue growth in which the government's analytical and political attention focuses only on how to modify this year's spending plan based on revenues anticipated in the next year. It happens because the current level of expenditures can be funded with relatively little controversy (Kavanagh, Johnson, \& Fabian, 2011).

To handle this issue, priority-driven budgeting is a common sense, strategic alternative to incremental budgeting. Priority budgeting represents a fundamental change in the way resources is allocated. It is the practice of developing budgets based on the relationship between program funding levels and expected results from that program. Administrators can use the priority-based budgeting process to develop more cost efficient and 
effective budgeting outlays long-term. Fan and Rao (2003) suggest that government expenditure, with its multitude of categories, needs to be examined from the perspective of wealth creation and poverty alleviation. Such a carefully targeted analysis would enable government to better assess the efficiency and effectiveness of its spending and make changes where necessary.

Priority budgeting is both a philosophy of how to budget scarce resources and a structured, although flexible, step-by-step process for doing so (Fan \& Rao, 2003; Kavanagh et al., 2011). The philosophy of priority-driven budgeting is that resources should be allocated according to how effectively a program or service achieves the goals and objectives that are of greatest value to the community (Norton, 2002). In a priority-driven approach, a government identifies its most important strategic priorities, and then, through a collaborative, evidence-based process, ranks programs or services according to how well they align with the priorities. The government then allocates funding in accordance with the ranking.

The government policy in determining the prioritized economic sectors in its public budgeting affects long-run economic growth based upon the view that a right budgeting policy leads to better resource allocation and a more productive public sector. Oates (1993) argued that this might be because locally determined policies were better able to take account of regional and local conditions through the provision of public goods, such as infrastructure and education. Meanwhile, Brennan and Buchanan (1980) believed that the competition among different levels of government had promoted lower tax rates and the efficient production of public goods under revenue constraints. Vazques and Mc Nab (2002) added that proper budgeting policy provided incentives for local governments to innovate in the production and supply of public goods and services.

The size and structure of public expenditure will determine the pattern and form of growth in output to the economy.
Analysis of the relationship between government spending on public infrastructure and economic growth is especially important in developing countries, most of which have experienced increasing levels of public expenditure overtime (World Bank, 1994). The work of Rostow (1960) and Musgrave (1974) reveals that government expenditure is relatively high in the early stages of development, because the state is required to invest in the social overhead capital (such as schools, universities and hospitals). Government takes the active roles in these investments due to private savings are insufficient to finance these essential expenditures. However, this role will be decreasing as the economy starts to grow in which particular investments increase proportionally with respect to public investments, and public expenditure falls. In the other words, it supports the basic idea of priority-driven budgeting implementation in developing countries, like Indonesia.

The emerging country's government concentrates its public expenditure on education, health, roads, electricity, and water supply those are necessities to launch the economy from the traditional stage to the take off stage of economic development (Laitner, 2000; Musgrave, 1974; Rostow, 1960). This policy relates to the seminal work of Kuznets (1973), which listed structural transformation as one of the six main features of modern economic growth. He defined the transformation as the reallocation of economic activity across three broad sectors (agriculture, manufacturing, and services) that accompany the process of contemporary economic growth.

Therefore, we hypothesize the association between priority-driven budgeting and economic structural transformation as follows:

$\mathbf{H}_{1}$ : priority-driven budgeting influences structural transformation. 


\section{Priority-Driven Budgeting Policy, Regional Inequality and Poverty Reduction}

Public investments, which are one of the development budget elements, have contributed significantly to agricultural growth and rural poverty reduction in rural areas and also to urban poverty reduction through growth in the national economy. However, despite these successes, many governments of developing countries still face severe budget constraints to implement development programs. It means that public resources need to be more effectively targeted to the sectors and regions that can generate the largest amount of economic growth and poverty reduction (Fan, Hazell \& Thorat, 2000).

In case of China, government spending on rural infrastructure (roads, electricity, and telecommunications) had a substantial impact on poverty and inequality, mainly through improved opportunities for nonfarm employment and increased rural wages. Meanwhile, investments in irrigation had only a modest impact on rural poverty and inequality (Fan, Zhang \& Zhang, 2004). The similar case happened in Thailand in which additional government spending on agricultural R\&D improved agricultural productivity the most and has the second-largest impact in reducing rural poverty. Meanwhile, investments in rural electrification, road expenditure, and education had a significant impact on rural poverty and regional inequality as well (Fan, Jitsuchon \& Methakunnavut, 2004). In case of India, Amis and Kumar (2000) suggested that the provision of physical and social infrastructure is important for poverty reduction. In the context of global comparison, the study of Canning and Bennathan (2000) that compared the relative impact of infrastructure investment in electricity generation and paved roads in 52 and 41 countries, respectively, found that the rate of return to infrastructure investment may vary depending on the income level of the country and the type of infrastructure. The study also suggested that infrastructure in isolation had limited impacts on economic growth, and that there should be a mixture of physical and human capital investments to maximize the return.

Those findings were in line with the report of Department for International Development/DFID (2002). It identified the various channels through which investment in infrastructure can contribute to sustainable growth, such as improving access to schools and health centers and improving environmental conditions. The work of Jalilian and Weiss (2004) that explores the nexus between infrastructure, growth and poverty using samples of countries from Africa, Asia and Latin America, finds that while infrastructure investment in general has a role to play in poverty reduction, physical infrastructure investment needs to be very substantial and must be supported by factors such as improvement in social infrastructure so as to promote rapid reductions in poverty. Meanwhile, Ogun (2010) indicate that investment in social infrastructure has greater potential to reduce poverty than investment in physical infrastructure in Nigeria. Ahmad and García-Escribano (2008) added that higher income levels enabled lower level governments to better respond to the population's request for specific types of expenditures. The authors found that levels of poverty and income across states were negatively related. Based on those empirical findings, we proposed the following hypothesis:

$\mathbf{H}_{2}$ : priority-driven budgeting negatively influences regional inequality and poverty reduction.

\section{Economic Structure Transformation}

In this paper, we define (economic) structural transformation as a fast economic growth accompanied by diversification and technological upgrading of production and exports, increasing international competitiveness, and expanding employment opportunities that result in shared prosperity. Therefore, it is more than just growth or poverty reduction. 
Structural transformation has become hot issue in the policy debate of developed and developing countries where various observers have claimed that the sectoral reallocation of economic activity is inefficient, and calls for government intervention (Hayami \& Ruttan, 1970, 1985; Herrendorf \& Valentinyi, 2006; Young, 2008). Bah (2009) reports that many developing countries are following processes those are very different from the path of developed countries. Bah (2009) finds that developing countries are the least productive in agriculture, followed by services and then manufacturing.

This finding challenges the basic premise that structural transformation implies breaking down the spatial, economic, and institutional barriers that limit a society's capacity for growth. Consequently, it may demand new technology, better use of existing technology, or simply innovativeness that enables a producer to organize his production differently when incentives are provided. In the context of developing countries, the governments' spending budgets failed to meet this objective (Echevarria, 1997; Kongsamut et al., 2001; Laitner, 2000; Gollin et al., 2002, 2007).

Meanwhile, the results of Aschauer (1989) seem to indicate that productivity growth, which is considered as the main objective of structural transformation, is closely linked with the existence of paved roads and highways, mass public transportation, sewage and running water systems - all key components of what constitutes basic infrastructure. The findings pull out the study of Tazi and Zee (1997) in which they argue that growth and government spending is in no way correlated. Devarajan et al. (1996) find that growth is positively impacted by the expansion of the public segment of expenditure. Nonetheless, these authors also argue that excessive productive expenditure has the same negative impact as nonproductive expenditure. In the context of civic spending financed by aid, Gomanee, Morrissey, Mosley, and Verschoor (2003) find that growth is positively related to the 'pro-poor' public expenditure. Their findings support the arguments of positive effect of proper public spending on increased regional welfare.

On the other hand, referring to macroeconomic literature (Fernald, 1999), certifies that, in Western economies United States included - the augment in productivity has been closely tied with public funds being earmarked for basic infrastructure, such as roads, seaports, airports, and railways' development (Kim, 1995; 2004). However, Logan (1972) argued that the drive toward a high rate of growth based on industrialization might lead to a movement of the most productive resources to specific areas of concentrated development. At this point, policy conflicts may emerge. If locational efficiency is used as the sole criterion for investment, regional imbalance will most likely increase (Syrquin, 1988). This may lead to pressure to disperse the benefits of growth evenly throughout the nation, which, in turn, could slow the rate of national growth. This finding reflects a disadvantage of structural transformation on economic development in which it leads to regional inequality as India has experienced in 1990s (Bhattacharya \& Sakthivel, 2004). However, these imbalances in regional economic development and the lack of spatial integration can both be traced; therefore, to a spatial organization that did not allow free movement of production factors (labor, capital, entrepreneurs, information) throughout the nation (Venables \& Kanbur, 2003). On another scale, Williamson (1964) showed that regional inequalities in developing nations may actually increase with industrialization up to a point when agglomeration diseconomies lead to a dispersion of industry and more regional equality.

Those findings closely relate to the seminal work of Kuznets (1966), which identified the shift of resources from agriculture to industry as the central feature of this transformation. The high price elasticity of demand for industrial goods also accelerated the demand for industrial goods and facilitated the shift of factors from agriculture to industry (Chenery \& 
Syrquin, 1979). In less developed countries, this shift has also triggered a migration from rural to urban locations leading to take place ahead of the growth of demand for labor and an increase of expected income more than current wages (Lewis 1954; Fan, 1978). Urban sprawl, as an impact of structural transformation, has a number of negative consequences and thus has been extensively criticized for being inefficient, inequitable and environmentally insensitive (Brueckner,
2000; Carruthers, 2002; Carruthers \& Ulfarsson, 2002; Smart Growth BC, 2001).

In the centre of inconclusive findings and arguments, however, we hypothesize the relationship between (economic) structural transformation and regional inequality as follows:

$\mathrm{H}_{3}$ : structural transformation negatively influences regional inequality.

We summarize all proposed hypotheses as seen in Table 1.

Table 1: Summary of Hypotheses

\begin{tabular}{|l|l|}
\hline Hypothesis 1 & Priority-driven budgeting influences structural transformation \\
\hline Hypothesis 2 & $\begin{array}{l}\text { Priority-driven budgeting negatively influences regional } \\
\text { inequality and poverty reduction }\end{array}$ \\
\hline Hypothesis 3 & $\begin{array}{l}\text { Structural transformation negatively influences regional } \\
\text { inequality }\end{array}$ \\
\hline
\end{tabular}

Therefore, we model the hypotheses testing in the following research framework:

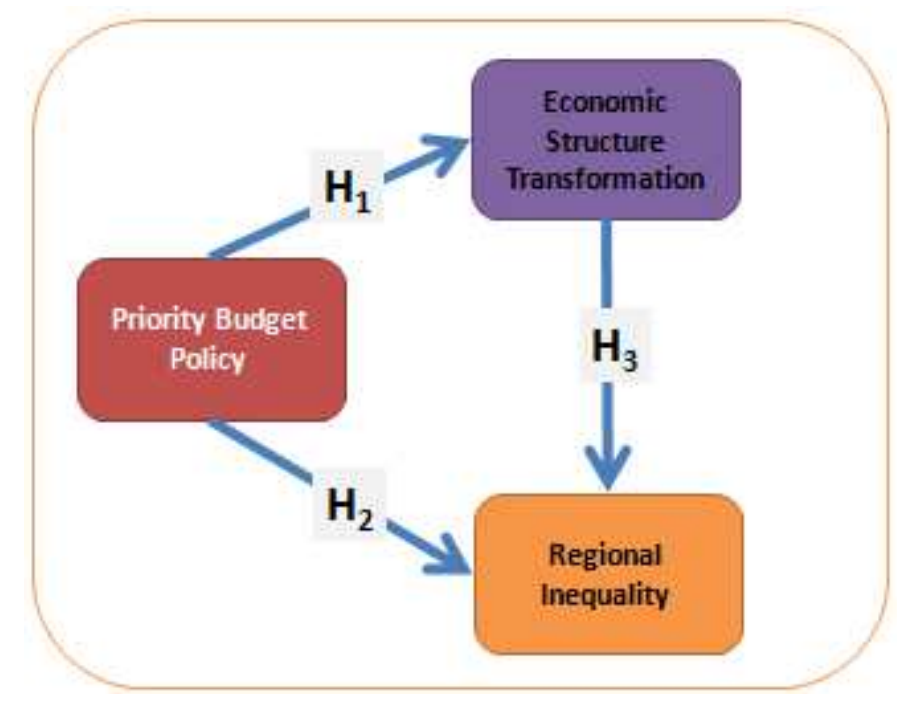

Figure 1: Research Model of Priority Budget Policy and Regional Inequality

Our study is different from prior studies in terms of providing the effects of prioritydriven budgeting and structural transformation on regional inequality and poverty reduction. Specifically, it tests structural transformation as the intervening variables in the linkage of government expenditure in physical and social infrastructures on balancing the regional income and reducing the poverty. It becomes important since Law No. $32 / 2000$ on Local Autonomy gives many 
autonomous Indonesian local governments have more power to manage and allocate its own local revenue and spending. However, the local government budget policy is still far away from the intended objective, i.e. sustainable regional economic growth. The results will provide valuable and recent information on the test of whether the prioritization of infrastructure projects of government is coherent with the developmental needs of the regions and provinces or not.

\section{Methodology}

To achieve the objective of the study, quarterly data for the period 2007:12011:4 were employed. To get the structural transformation value, we used shift-share analysis. We attempted to determine how much of business sectors could attribute to national trends and how much was due to unique regional factors. Shift share helps answer why certain economic sectors are growing or declining in a regional industry, cluster, or occupation. Therefore, we employed the shift-share formula as follows:

$$
\begin{gathered}
\mathrm{PS}_{\text {iregency }}^{\mathrm{t}}=\mathrm{Y}_{\text {iregency }}^{\mathrm{t}-1} \mathrm{X}\left(\frac{\mathrm{Y}_{\text {province }}^{\mathrm{t}}}{\mathrm{Y}_{\text {province }}^{\mathrm{t}-1}}-1\right) \\
\mathrm{P}_{\text {iregency }}^{\mathrm{t}}=\mathrm{Y}_{\text {iregency }}^{\mathrm{t}-1} \mathrm{X}\left(\frac{\mathrm{Y}_{\text {iprovince }}^{\mathrm{t}}}{\mathrm{Y}_{\text {iprovince }}^{\mathrm{t}-1}}-\frac{\mathrm{Y}_{\text {province }}^{\mathrm{t}}}{\mathrm{Y}_{\text {provnce }}^{\mathrm{t}-1}}\right) \\
\mathrm{D}_{\text {iregency }}^{\mathrm{t}}=\mathrm{Y}_{\text {iregency }}^{\mathrm{t}-1}\left(\frac{\mathrm{Y}_{\text {iregency }}^{\mathrm{t}}}{\mathrm{Y}_{\text {iregency }}^{\mathrm{t}-1}}-\frac{\mathrm{Y}_{\text {iprovince }}^{\mathrm{t}}}{\mathrm{Y}_{\text {iprovince }}^{\mathrm{t}-1}}\right)
\end{gathered}
$$

$$
\Delta \mathrm{Y}=\mathrm{PS}+\mathrm{P}+\mathrm{D}
$$

where $\mathrm{Y}$ is Gross Domestic Regional Product (GDRP), $i$ is the number of subeconomic sectors (nine sub-economic sectors), PS is proportional share, $\mathrm{P}$ is

$$
\mathrm{I}_{\mathrm{w}}=\frac{\sqrt{\sum_{\mathrm{i}=1}^{\mathrm{n}}\left(\mathrm{Y}_{\mathrm{i}}-\overline{\mathrm{Y}}\right)^{2} \frac{\mathrm{p}_{\mathrm{i}}}{\mathrm{P}}}}{\overline{\mathrm{Y}}}, 0<\mathrm{I}_{\mathrm{w}}<1
$$

where Iw is Williamson Index, Yi is GDRP per capita, $\bar{Y}$ is GDP per capita, $\mathrm{P}_{\mathrm{i}}$ is regional population, and $\mathrm{P}$ is national population. Then, we grouped local government budget into three main posts, i.e. education, health, and infrastructure, which Ogun (2010)

$$
\begin{aligned}
& Y_{1 \text { atau } 2}=A \cdot X_{1}^{b} X_{2}^{c} X_{3}^{d} \\
& Y_{2}=A \cdot Y_{1}^{e} \\
& L n Y_{1}=\ln A \pm b \ln X_{1} \pm c \ln X_{2} \pm d \ln X_{3} \\
& L n Y_{2}=\ln A \pm b \ln X_{1} \pm c \ln X_{2} \pm d \ln X_{3}
\end{aligned}
$$




$$
\operatorname{Ln} Y_{2}=\ln A \pm e \ln Y_{1}
$$

where LnY1 is structural transformation, $\mathrm{LnY} 2$ is regional inequality; meanwhile, $\mathrm{X} 1$, $\mathrm{X} 2$, and $\mathrm{X} 3$ is local government budget in education, health, and infrastructure, respectively.

Table 1 reveals the government budget allocation for three main economic sectors. It reflects the government budget priority
(7)

in the last five years. Local government paid more attention and main concern on education sector than health and infrastructure in which its total allocation growth rate had doubled $5.57 \%$ in 2007 became $11.10 \%$ in 2011 ) within five years. Meanwhile, ironically, the allocation for infrastructure development had decreased around $50 \%$ in the same period.

Table 1: Regency Budget Allocation (2007-2011)

\begin{tabular}{|c|c|c|c|c|c|}
\hline & 2007 & 2008 & 2009 & 2010 & 2011 \\
\hline Sector & \multicolumn{5}{|c|}{ Education } \\
\hline $\begin{array}{r}\text { Total Expenditure } \\
\text { (Rp) }\end{array}$ & $59,671,687,865$ & $70,744,474,146$ & $111,162,858,200$ & $99,543,808,900$ & $198,389,384,537$ \\
\hline Total Budget (Rp) & 1.069 .649 .333 .590 & 1.250 .601 .634 .668 & 1.318 .235 .177 .352 & 1.409 .834 .108 .800 & 1.786 .448 .175 .612 \\
\hline $\begin{array}{r}\text { Expenditure/Budget } \\
(\%) \\
\end{array}$ & 5.57 & 5.65 & 8.43 & 7.06 & 11.10 \\
\hline Sector & \multicolumn{5}{|c|}{ Health } \\
\hline $\begin{array}{r}\text { Total Expenditure } \\
\text { (Rp) }\end{array}$ & $36,899,122,840$ & $44,799,218,401$ & $44,265,853,945$ & $38,785,178,600$ & $52,542,527,622$ \\
\hline Total Budget (Rp) & 1.069 .649 .333 .590 & 1.250 .601 .634 .668 & 1.318 .235 .177 .352 & 1.409 .834 .108 .800 & 1.786 .448 .175 .612 \\
\hline $\begin{array}{r}\text { Expenditure/Budget } \\
(\%) \\
\end{array}$ & 3.44 & 3.58 & 3.35 & 2.75 & 2.94 \\
\hline Sector & \multicolumn{5}{|c|}{ Infrastructure } \\
\hline $\begin{array}{r}\text { Total Expenditure } \\
(\mathrm{Rp})\end{array}$ & $287,964,843,899$ & $267,799,228,276$ & $258,811,204,641$ & $236,533,745,700$ & $242,003,586,400$ \\
\hline Total Budget (Rp) & 1.069 .649 .333 .590 & 1.250 .601 .634 .668 & 1.318.235.177.352 & 1.409 .834 .108 .800 & 1.786.448.175.612 \\
\hline $\begin{array}{r}\text { Expenditure/Budget } \\
(\%)\end{array}$ & 26.92 & 21.41 & 19.63 & 16.77 & 13.54 \\
\hline
\end{tabular}

\section{Source: Elaborated data}

The differential shift analysis (Table 2) demonstrated that industrial and agricultural sectors were highly competitive sectors compared with other ones in which experienced high growth rate or fast shift. A positive value of the differential shift-share in an economic sector reflected its high and swift competitive growth. 
Table 2: Differential Shift-Share Results

\begin{tabular}{|c|c|c|c|c|c|c|}
\hline \multirow{3}{*}{ No. } & \multirow{3}{*}{$\begin{array}{c}\text { Economic } \\
\text { Sectors }\end{array}$} & \multicolumn{2}{|c|}{ Regency } & \multicolumn{2}{|c|}{ Regency } & \multirow[b]{2}{*}{ Ds } \\
\hline & & \multirow[b]{2}{*}{2011} & \multirow{2}{*}{$\begin{array}{c}2011 \\
\text { EN,I,t/EN I,t- } \\
\text { n }\end{array}$} & \multirow[b]{2}{*}{2007} & \multirow[b]{2}{*}{ b $\times \mathbf{c}$} & \\
\hline & & & & & & a-d \\
\hline & & (a) & (b) & (c) & (d) & (e) \\
\hline 1 & Agriculture & $5,284,409.68$ & 1.7224 & $2,898,466.98$ & $4,992,319.53$ & $292,090.15$ \\
\hline 2 & $\begin{array}{l}\text { Mining \& } \\
\text { Quarrying }\end{array}$ & $427,351.75$ & 1.8051 & $261,308.39$ & $471,687.77$ & $(44,336.02)$ \\
\hline 3 & Manufacture & $22,158,781.84$ & 1.5522 & $12,708,098.77$ & $19,725,510.91$ & $2,433,270.93$ \\
\hline 4 & Gas and Electricity & $91,437.73$ & 1.5633 & $60,047.70$ & $93,872.57$ & $(2,434.84)$ \\
\hline 5 & Construction & $1,061,233.09$ & 1.9124 & $564,118.11$ & $1,078,819.47$ & $(17,586.38)$ \\
\hline 6 & Trade & $9,334,037.34$ & 1.7228 & $5,609,899.56$ & $9,664,734.96$ & $(330,697.62)$ \\
\hline 7 & Transportation & $681,999.98$ & 1.7620 & $439,155.70$ & $773,792.34$ & $(91,792.36)$ \\
\hline 8 & Financial & $1,093,662.07$ & 1.8888 & $575,715.56$ & $1,087,411.55$ & $6,250.52$ \\
\hline 9 & Service & $4,992,919.36$ & 1.9635 & $2,925,176.76$ & $5,743,584.57$ & $(750,665.21)$ \\
\hline & GDRP & $45,125,832.84$ & & $26,041,987.53$ & & $1,494,099.16$ \\
\hline
\end{tabular}

Source: BPS, Deli Serdang Regency (2012)

The structural transformation shift analysis (Table 3) showed that manufacturing industry was the economic sectors experiencing the biggest transformation. It increased in terms of the size relative to other sectors. It informed us that this regency had reallocated its economic activity across the broad sectors agriculture, manufacturing, and services. It means that this regency is developing in which the process of structural transformation from agriculture into manufacturing and services involves a shift of labor out of rural areas and into urban ones. The fact is in line with the "labor pull" approach describing how a rise in nonagricultural productivity (an industrial revolution) attracts underemployed labor from agriculture into the modern sector (Lewis, 1954; Harris \& Todaro, 1970; Hansen \& Prescott, 2002; Lucas, 2004; Alvarez-Cuadrado \& Poschke, 2011).

Tabel 3: Regency's Structural Transformation Shift (2007-2011)

\begin{tabular}{|r|l|r|r|r|r|}
\hline No & \multicolumn{1}{|c|}{$\begin{array}{c}\text { Economic } \\
\text { Sectors }\end{array}$} & \multicolumn{1}{|c|}{$\begin{array}{c}\text { National } \\
\text { Growth }\end{array}$} & $\begin{array}{c}\text { Proportional } \\
\text { Share }\end{array}$ & $\begin{array}{c}\text { Differential } \\
\text { Share }\end{array}$ & $\begin{array}{c}\text { Structural } \\
\text { Transformation }\end{array}$ \\
\hline $\mathbf{1}$ & Agriculture & $2,109,644.48$ & $(15,652.99)$ & $292,090.15$ & $1,833,207.32$ \\
\hline $\mathbf{2}$ & $\begin{array}{l}\text { Mining \& } \\
\text { Quarrying }\end{array}$ & $190,192.89$ & $20,206.72$ & $(44,336.02)$ & $214,322.19$ \\
\hline $\mathbf{3}$ & Manufacture & $9,249,569.02$ & $(2,231,882.02)$ & $2,433,270.93$ & $9,048,180.11$ \\
\hline $\mathbf{4}$ & Gas and & $43,705.62$ & $(9,876.70)$ & $(2,434.84)$ & $56,017.16$ \\
\hline $\mathbf{5}$ & Construction & $410,592.45$ & $104,131.75$ & $(17,586.38)$ & $324,047.09$ \\
\hline $\mathbf{6}$ & Trade & $4,083,156.27$ & $(28,134.24)$ & $(330,697.62)$ & $4,441,988.14$ \\
\hline $\mathbf{7}$ & Transportation & $319,638.76$ & $15,018.50$ & $(91,792.36)$ & $396,412.63$ \\
\hline $\mathbf{8}$ & Financial & $419,033.63$ & $92,715.30$ & $6,250.52$ & $320,067.82$ \\
\hline $\mathbf{9}$ & Service & $2,129,085.15$ & $689,365.77$ & $(750,665.21)$ & $2,190,384.59$ \\
\hline & Total & $18,954,618.28$ & $(1,364,107.93)$ & $1,494,099.16$ & $18,824,627.04$ \\
\hline
\end{tabular}

Source: BPS, Deli Serdang Regency (2012) 
The regional inequality result for 22 districts in Deli Serdang Regency revealed that there was high regional inequality between districts, which the index score was closed to 1.

$\mathrm{Iw}=\sqrt{\frac{7,889,577.32}{4,554.35}}$

$\mathrm{Iw}=0.62$

It means that in the certain degree the local development has created divergence between districts and one of the possible major causes is the government budget priority (Echevarria, 1997; Kongsamut et al., 2001; Kavanagh et al., 2011).

\section{Research Results and Discussion}

In this study, the result of first hypothesis testing (Table 4) reveals that local government budget allocation on health and infrastructure play important and positive effect on the strengthened structural transformation in Deli Serdang regency. It means that priority-driven budget on those posts has influenced economic sectors' transformation positively.

Table 4: Test of Hypothesis 1

\begin{tabular}{|l|l|r|r|r|r|c|}
\hline \multicolumn{2}{|l|}{ Model } & \multicolumn{2}{c|}{$\begin{array}{c}\text { Unstandardized } \\
\text { Coefficients }\end{array}$} & $\begin{array}{c}\text { Stand. } \\
\text { Coeff. }\end{array}$ & \multicolumn{2}{c|}{ t-Distribution } \\
\hline & & B & Std. Error & Beta & t-ratio & \multicolumn{1}{c|}{. 05} \\
\hline 1 & (Constant) & - & 25.920 & & -5.596 & 2,110 \\
\hline & $\ln \left(\mathrm{X}_{1}\right.$ - education) & .099 & .148 & .129 & .669 & 2,110 \\
\cline { 2 - 7 } & $\ln \left(\mathrm{X}_{2}\right.$ - health) & 1.470 & .689 & .404 & 2.133 & 2,110 \\
\cline { 2 - 7 } & $\begin{array}{l}\ln \left(\mathrm{X}_{3}-\right. \\
\text { infrastructure })\end{array}$ & 4.546 & .741 & .869 & 6.138 & 2,110 \\
\hline
\end{tabular}

The finding is in line with prior studies (Laitner, 2000; Musgrave, 1974; Rostow, 1960). It confirms that economic transformation requires financial resources-to pay for infrastructure, import machines and technology, to educate and train skilled workers. Any structural transformation involves costs, trade-offs, and uncertainties. It affirms that budgeting and public expenditure management are critical. Priority-driven budgeting enables a structural transformation in economic sectors, such as in agriculture, by shifting to high-value crops, which are more profitable than traditional crops such as rice and corn. Such kind of transformation requires rapid technological change and improved rural infrastructure, which clearly call for increased investments in infrastructure. It also demands an equitable and efficient use of public resources or, in the other words, good priority-driven budgeting.

The test of second hypothesis (Table 5) shows that priority-driven budgeting can minimize regional inequality. It has a significant and negative effect on regional divergence. It means that any increase in education, health, or infrastructure budget allocation will decrease local inequality leading to poverty reduction as well. 
Table 5: Test of Hypothesis 2

\begin{tabular}{|l|r|r|r|r|c|}
\hline \multirow{2}{*}{ Model } & \multicolumn{2}{|c|}{$\begin{array}{c}\text { Unstandardized } \\
\text { Coefficients }\end{array}$} & $\begin{array}{c}\text { Standardized } \\
\text { Coefficients }\end{array}$ & \multicolumn{2}{c|}{ t-Distribution } \\
\cline { 2 - 6 } & $\mathrm{B}$ & $\begin{array}{c}\text { Std. } \\
\text { Error }\end{array}$ & Beta & $\begin{array}{c}\mathrm{t}- \\
\text { ratio }\end{array}$ & t.05 \\
\hline (Constant) & 13.406 & 3.347 & & 4.006 & 2,110 \\
\hline $\begin{array}{l}\ln \left(\mathrm{X}_{1}-\right. \\
\text { education })\end{array}$ & -.097 & .019 & -.752 & - & 2,110 \\
\hline $\ln \left(\mathrm{X}_{2}-\right.$ health) & -.176 & .089 & -.287 & - & 2,110 \\
\hline $\begin{array}{l}\ln \left(\mathrm{X}_{3}-\right. \\
\text { infrastructure })\end{array}$ & -.267 & .096 & -.302 & - & 2,110 \\
\hline \multicolumn{2}{|l|}{ a. Dependent Variable $:\left(\mathrm{Y}_{2}-\right.$ regional inequality) } & & \\
\hline
\end{tabular}

The finding confirms previous studies (Canning \& Bennathan, 2000; Fan et al., 2000; Jalilian \& Weiss, 2004) that prioritized public budget on certain posts, such as education, health, and infrastructure development affect more balanced income across regions. It reveals that budget priority on infrastructure has the biggest effect in reducing inequality and poverty. It means that the more a region is open due to the availability of transportation infrastructures, the more equalized-income and the less poverty a region. The same thing happens as well for the policy of high spending in education and health posts can assist in the accumulation of human capital. It demands that any local government when determines the public budgets should thus consider how to manage public expenditures and revenues to improve the distribution of income.

This finding affirms the virtuous circle between economic and social policy, i.e. high social spending leading to higher economic growth which, in turn, delivers more resources for social investment, and the work of Roberts (2003) that finds several important advantages of using priority-based budgeting. He believes that this type of budgeting process is a very useful way to bring about more clarity about priorities. Whether these priorities are present at a national, state or sector level, he argues, priority-driven budgeting not only helps identify these priorities, but also it targets them more specifically through the public spending programs, and it boosts coordination among the agencies and departments involved by clearly designating roles and responsibilities. He adds that coordination among the entities involved, paired with clear responsibilities are expected to lead to increased efficiency and effectiveness of the public spending.

Meanwhile, the test of third hypothesis (Table 6) informs us that structural transformation affects negatively regional inequality. It means that any increase in Deli Serdang regency's nine economic sectors will reduce its local divergence. It supports the study of Devarajan et al. (1996) and Gomanee et al. (2003) that finds growth is positively impacted by the expansion of the public segment of expenditure. This research result is similar to Lorber's (2011) findings, which investigates the local disparities between Slovenian provinces. He found that regional inequalities were the result of structural inadequacy of local economies. He argues that deep structural economic changes will enable the creation and growth of highquality jobs leading to fewer disparities between regions. In order to do so, flexibility of the labor market and educational reforms will need to be implemented. In the other words, the regions that optimize the development potentials and expand their economies 
using the endogenous approach will come out as winners in the race of combating regional inequalities.

Table 6: Test of Hypothesis 3

\begin{tabular}{|c|c|c|c|c|c|}
\hline & \multirow{2}{*}{ Model } & \multicolumn{2}{|c|}{$\begin{array}{l}\text { Unstandardized } \\
\text { Coefficients }\end{array}$} & \multirow{2}{*}{$\begin{array}{c}\begin{array}{c}\text { Standardized } \\
\text { Coefficients }\end{array} \\
\text { Beta } \\
\end{array}$} & \multirow[b]{2}{*}{$\mathrm{t}$} \\
\hline & & $\mathrm{B}$ & $\begin{array}{l}\text { Std. } \\
\text { Error }\end{array}$ & & \\
\hline \multirow[b]{2}{*}{1} & (Constant) & -3.299 & .438 & & -7.534 \\
\hline & $\begin{array}{l}\text { In }\left(\mathrm{Y}_{1}-\mathrm{structural}\right. \\
\text { transformation) }\end{array}$ & -.062 & .033 & -.405 & -1.877 \\
\hline
\end{tabular}

Economic transformation can change poor developing countries into prosperous countries, with a dramatic fall in poverty rates. China stands out as a notable example. The transformation occurs when a poor, rural-based country becomes a middle-income country with the growth of industry and services sectors. Productivity and income per capita as well as job creation grow fast. In case of Deli Serdang regency, structural transformation has effectively reduced inequality in its 22 districts.

To test whether structural transformation serves as intervening variable or not, we employed a path analysis as shown in Table 7.

Table 7: The Effects of Observed Variables (Direct, Indirect, and Total)

\begin{tabular}{|c|c|c|c|}
\hline Effect of between variables & $\begin{array}{l}\text { Direct } \\
\text { effect }\end{array}$ & $\begin{array}{c}\text { Indirect effect } \\
\text { through Structural } \\
\text { Transformation }\end{array}$ & Total effect \\
\hline Education $\rightarrow$ Structural Transformation & 0.099 & - & 0.334 \\
\hline Health $\rightarrow$ Structural Transformation & $1.470^{* *}$ & - & 0.314 \\
\hline $\begin{array}{l}\text { Infrastructure } \rightarrow \text { Structural } \\
\text { Transformation }\end{array}$ & $4.546^{* *}$ & - & 4.546 \\
\hline Education $\rightarrow$ Regional Inequality & $\begin{array}{c}- \\
0.097^{* * *}\end{array}$ & $\begin{array}{c}(0.099) \times(-0.062)=- \\
0.00198\end{array}$ & $-0.097-0.00198=-0.09898$ \\
\hline Health $\rightarrow$ Regional Inequality & $-0.176^{*}$ & $\begin{array}{c}(1.470) \times(-0.062)=- \\
0.09114\end{array}$ & $-0.176-0.09114=-0.26714$ \\
\hline Infrastructure $\rightarrow$ Regional Inequality & $-0.267^{* *}$ & $\begin{array}{c}(4.546) \times(-0.062)=- \\
0.281852\end{array}$ & $\begin{array}{c}-0.267-0.281852=- \\
0.548852\end{array}$ \\
\hline $\begin{array}{l}\text { Structural Transformation } \rightarrow \text { Regional } \\
\text { Inequality }\end{array}$ & $-0.062^{* *}$ & - & -0.062 \\
\hline
\end{tabular}

Note: ${ }^{* * *} \mathbf{p}<0.01 ;{ }^{* *} \mathbf{p}<0.05 ;{ }^{*} \mathbf{p}<0.10$

The results demonstrate that structural transformation performs as mediating variable in the relationship between priority-driven budgeting and regional inequality. The effect of government budget allocation on regional divergence through structural transformation has reduced imbalanced local income drastically. It happens especially in health and infrastructure posts' allocation. Government budget provision in health has increased $58 \%$ in reducing regional divergence; meanwhile, government spending in infrastructure has doubled its impact to diminish local disparity as well. The findings are in line with the work of 
Jahan and Mcleery (2005). They argue that infrastructure development can lead to regional divergence and poverty reduction through direct or indirect channels. Through the direct channel, it reduces income inequality and poverty as people's access to health and educational services improves, there is cleaner energy available and the government provides for protection against national disasters. The indirect effect of infrastructure provision on poverty occurs when the productivity of workers is increased, transport costs are reduced and more employment is generated, thereby leading to economic growth. This implies that infrastructure provision can have economic and social impacts on the lives of people.

It implies that to create balanced income and reduced poverty a proper government's budget priority is a must. It is also critical for civil society to engage in all stages in the budget cycle not only because they can contribute valuable technical skills to the process, but they also have connections with the community that enable them to bring critical information about the public's needs and priorities to budget debates. In addition to representing the concerns of marginalized people, civil society can strengthen and support the ability of the poor and most vulnerable to participate in the budget process.

Learning from other country's experience, the success of the UK Regional Development Agencies (RDA) in implementing priority-based budgeting was in large part due to coordination, cohesion and alignment of resources. Referring to Rowan (2013), the success lies at more local prioritization for investment and alignment of public resources, plus private sector leverage. It leads to deliver better policy outcomes.

Despite the countries' vast differences in economic systems, natural resource endowments, socioeconomic conditions, and size, our empirical findings offer some important lessons:

1. Spending on agricultural research, education, and rural infrastructure are the three most effective types of public spending for promoting agricultural growth and reducing poverty.

2. Rural road investment contributes not only to rural growth and poverty reduction but also to urban growth and poverty reduction.

3. Government spending on irrigation played an important role in promoting agricultural growth and reducing poverty in the past, but today this type of spending provides smaller marginal poverty and growth returns to many Asian countries.

The findings also indicate that different spending priorities are needed during different stages of development; "one-sizefits-all" strategies do not work. During the first phase, strategies should focus on reducing widespread poverty through broad-based economic growth that reaches rural areas. In subsequent phases, more direct attention should be focused on lagging sectors and regions, as well as on poverty at the community and household levels, in order to reduce the poverty and income inequalities that arise and persist despite reform.

Related to the research site, which located in a developing country, this study suggests good local government governance. It is related to a view that in developing countries characterized by weak governance and institutions, the tendency for government officials to be corrupt is very high (Ali \& Pernia, 2003). Therefore, in these scenario decisions to invest in infrastructure may be distorted, thereby lowering the contribution of infrastructure to growth and diverting benefits intended for reducing the income inequality. A proper and well-governed government budgeting is a precondition.

\section{Conclusion}

The study on the interrelated nexus of priority-based budgeting, structural transformation, and regional inequality reveals that government budget allocation in education, health, and infrastructure affects economic structural transformation and local inequality. Prioritized budget 
allocation has strengthened and increased economic transformation. Meanwhile, at the same time, it has diminished local income disparity in Deli Serdang regency. The findings also demonstrate a negative relationship between structural transformation and regional divergence. In addition, structural transformation plays a role as intervening variable as well in the effect of priority-driven budgeting on local inequality.

Our findings affirm that priority-based budgeting provides a new lens that produces powerful insights, and local governments that are using it are making significant breakthroughs. It implies that any government in developing countries needs to devote a substantial proportion of its budgetary allocations and spending to the development of social infrastructure, which comprises investment in education and health. Since investment in education and health contributes greatly to the development of human capital, increasing social infrastructure can help to improve the welfare of people in the urban areas.

On a last note, given that the development of essential and adequate infrastructure depends on governance, local development agencies have a crucial role to play in the reorientation of people and the strengthening of legal institutions to minimize the levels of corruption.

\section{References}

1. Ahmad, E. and Garcia-Escribano, $M$. (2008), 'Constraints to effective fiscal decentralization in Peru,' Working Paper 08-24, International Studies Program, Andrew Young School of Policy Studies, Georgia State Unversity. [Online], [Retrieved November 15, 2013], http://aysps.gsu.edu/isp/files/ ispwp0824.pdf

2. Akin, J., Hutchinson, P., and Strumpf, K. (2005), 'Decentralization and government provision of public goods: The public health sector in Uganda,' The Journal of Development Studies, 41(8), 1417-1443.
3. Ali, I., and Pernia, E. M. (2003), 'Infrastructure and poverty reduction: What is the connection?' ERD Policy Brief Series 15. Manila: Asian Development Bank.

4. Alonso, R., Judge, L. and Klugman, J. (2006), 'PRSPs and budgets: A synthesis of five case studies,' In Budget Support as More Effective Aid? ed. Stefan Koeberle, Jan Walliser, and Zoran Stavreski. Washington, DC: World Bank.

5. Alvarado, B. and Morón, E. (2008), 'Peru, hacia un presupuesto por resultados: afianzando la transparencia y rendición de cuentas,' Universidad del Pacífico. [Online], [Retrieved November 15, 2013] http://ciup.up.edu.pe/data/ciup/documen tos/20090109121703_DD-08-11.pdf

6. Alvarez-Cuadrado, F. and Poschke, M. (2011), 'Structural change out of agriculture: Labor push versus labor pull,' American Economic Journal: Macroeconomics, 3(3), 127-158.

7. Aschauer, D. A. (1989), 'Is public expenditure productive?' Journal of Monetary Economics, 23(2), 177-200.

8. Bhattacharya, B.B. and Sakthivel, S. (2004), 'Regional growth and disparity in India: Comparison of pre and post-reform decades,' Economic and Political Weekly, March 6, 1071-1077.

9. Bah, E. M. (2009), 'Structural transformation in developed and developing countries,' The University of Auckland Working Paper.

10. Bardhan, P. (1998), The state against society: The great divide in Indian social science discourse, eds. Bose, S. \& Jalal, A., Nationalism, Democracy and Development, Delhi: Oxford University Press.

11. Brennan, G. and Buchanan, J. (1980), The power to tax: Analytical foundations of a fiscal constitution, Cambridge: Cambridge Univ. Press.

12. Canning, D. and Bennathan, E. (2000), 'The social rate of return on infrastructure 
investments. WB Policy Research Working Paper 2. Washington, DC: World Bank.

13. Carruthers, J. (2002), 'The impact of state growth management programs: A comparative analysis,' Urban Studies, 39(11), 1959 - 1982.

14. Carruthers, J., and Ulfarsson, G. (2002), 'Fragmentation and sprawl: Evidence from interregional analysis,' Growth and Change, 33(3), 312-340.

15. Cavallo, E. and Daude, C. (2008), 'Public investment in developing countries: A blessing or a curse?' Research Department Working Papers 648. Inter-American Development Bank and Organization for Economic Cooperation and Development. [Online], [Retrieved November 15, 2013] http://www.iadb.org/research/pubhits.cf $\mathrm{m}$ ? pubid $=1726038$

16. Chenery, H.B. and Syrquin, M. (1979), Structural change and development policy. Oxford University Press, Oxford

17. Devarajan, S., Swaroop, V., and Zou, Heng-fu. (1996), 'The composition of public expenditure and economic growth,' Policy research department, The World Bank, in Journal of Monetary Economics, 37, pp. 313-344. [Online], [Retrieved November 15 , 2013] http://siteresources.worldbank.org/INTRE S/Resources/46923211074495 12766/6480831108140788422/The_Com position_of_Public_Expenditures_and_Econ omic_Growth.pdf

18. DFID, (2002). Making the Connections: Infrastructure for Poverty Reduction, London.

19. Estache, A., Gonzales, M., and Trujillo, L. (2007), 'Government expenditures on education, health and infrastructure: A naive look at levels, outcomes and efficiency,' Policy Research Working Paper 4219. World Bank. [Online], [Retrieved November

15 ,

2013]http://wwwwds.worldbank.org/serv let/WDSContentServer/WDSP/IB/2007/0 4/19/000016406_20070419160726/Rend ered/PDF/wps4219.pdf
20. Echevarria, C. (1997), 'Changes in sectoral composition associated with economic growth,' International Economic Review, 38(2), 431-452.

21. Fan, S., Hazell, P. and Thorat, S. (2000), 'Government spending, agricultural growth, and poverty in rural India,' American Journal of Agricultural Economics, 82(4), 1038-1051.

22. Fan, S., and Rao, N. (2003), 'Public spending in developing countries: Trends, determination and impact,' Discussion Paper No. 99. Environment and Production Technology Division. International Food Policy Research Institute. [Online], [Retrieved November 15, 2013] http://www.ifpri.org/sites/default/files/di vs/eptd/ dp/papers/eptdp99.pdf

23. Fan, S., Zhang, L. and Zhang, X. (2004), 'Investment, reforms, and poverty in rural China,' Economic Development and Cultural Change, 52(2), 395-422.

24. Fan, S., Jitsuchon, S. and Methakunnavut, N. (2004), 'The importance of public investment for reducing rural poverty in middle-income countries: The case of Thailand,' DSGD Discussion Paper 7 (Washington, DC: International Food Policy Research Institute).

25. Fernald, J. (1999). Roads to prosperity? Assessing the link between public capital and productivity, The American Economic Review, 89(3), pp. 619-638. [Online], [Retrieved November 15, 2013] http://www.jstor. org/stable/117036

26. Gollin, D., Parente, S. L., and Rogerson, R. (2002), 'The role of agriculture in development,' American Economic Review: Papers and Proceedings, 92(2), 160-164.

27. Gollin, D., Parente, S. L., and Rogerson, R. (2007), 'The food problem and the evolution of international income levels,' Journal of Monetary Economics, 54(4), 1230-1255.

28. Gomanee, K., Morrissey, O., Mosley, P. and Verschoor, A. (2003), 'Aid, pro-poor 
government spending and welfare,' CREDIT Research Paper 3. Nottingham: University of Nottingham.

29. Hansen, G. D. and Prescott, E. C. (2002), 'Malthus to Solow,' American Economic Review, 92(4), 1205-1217.

30. Harris, J. R. and Todaro, M. P. (1970), 'Migration, unemployment \& development: A two-sector analysis,' American Economic Review, 60(1), 126-42.

31. Hayami, Y., and Ruttan, V. W. (1970), 'Agricultural differences among countries,' The American Economic Review, 60(5), 895-911.

32. Hayami, Y., and Ruttan, V. W. (1985), Agricultural Development: An International Perspective, Baltimore: John Hopkins.

33. Herrendorf, B., and Valentinyi, A. (2006), 'Which sector make the poor countries so unproductive,' Arizona State University working paper.

34. Herrendorf, B., Rogerson, R., and Valentinyi, Á. (2013), 'Growth and structural transformation. NBER Working Paper No. 18996, pp. 1-113. [Online], [Retrieved November 15, 2013] http://www.nber.org/ papers/w18996

35. Holmes, M. and Evans, A. (2003), A review of experience in implementing medium-term expenditure frameworks in a PRSP context: A synthesis of eight country studies. Overseas Development Institute, London.

36. Jahan, S. and McCleery, R. (2005), Making infrastructure work for the poor. UNDP. [Online], [Retrieved November 15, 2013],

http://www.undp.org/poverty/docs/ fpage/Synthesisreport.pdf.

37. Jalilian, H., and Weiss, J. (2004), Infrastructure, growth and poverty: Some cross- country evidence. Paper presented at the ADB Institute annual conference on Infrastructure and Development: Poverty, Regulation and Private Sector Investment, 6 December. Tokyo.
38. Jerome, A., and A. Ariyo (2004), Infrastructure reform and poverty reduction in africa. african development and poverty reduction: The macro-micro linkage. TIP/DPRU Forum, 13-15 October, South Africa.

39. Kavanagh S. C., Johnson, J. and Fabian, C. (2011), Anatomy of a priority-driven budget process. Chicago: Government Finance Officers Association.

40. Kim, S. (1995), 'Expansion of markets and geographic distribution of economic activities: the trends in U.S. regional manufacturing structure, 1860-1987,' Quarterly Journal of Economics, 110(4), 881-908.

41. Kim, S. (2004), 'Industrialization and urbanization: did the steam engine contribute to the growth of cities in the United States?' Institute of European Studies-Occasional Papers, University of California, Berkeley.

42. Kongsamut, P., Rebelo, S. and Xie, D. (2001), 'Beyond balanced growth. Review of Economic Studies, 68(4), 869-882.

43. Kuznets, S. (1973), 'Modern economic growth: Findings and reflections. American Economic Review, 63(3), 247-258.

44. Laitner, J. (2000), 'Structural change and economic growth,' Review of Economic Studies, 67(3), 545-561.

45. Leruth, L., and E. Paul. (2006), 'A principal-agent theory approach to public expenditure management systems in developing countries,' Working Paper No. 204, International Monetary Fund, Washington, DC.

46. Lewis W.A. (1954), 'Economic development with unlimited supplies of labor,' Manchester School of Economics and Social Science, 22(2), 139-191

47. Logan, M. I. (1972, 'The spatial system and planning strategies in developing countries,' Geographical Review, 62(2), 229-244 
48. Lorber, L. (2011), 'Recent transformation of economic inequality in NUTS 3 regions in Slovenia,' Geoadria, 16(2), 237-251.

49. Lucas, R. E. (2004), 'Life earnings and rural-urban migration,' Journal of Political Economy, 112(S1), S29-S59.

50. Musgrave, R. (1974), Expenditure policy for development. University of Florida Press: Gainsville

51. Norton, A. (2002), What's behind the Budget? Politics, Rights, and Accountability in the Budget Process. Overseas Development Institute, London.

52. OECD. (1995), Budgeting for Results: Perspectives on Public Expenditure Management, Paris: Organization for Economic Co-operation and Development (OECD).

53. OECD. (2012), China in focus: Lessons and challenges, OECD, Paris. [Online], [Retrieved November 15, 2013] http://www.oecdchina.org

54. Ogun, T. P. (2010), 'Infrastructure and poverty reduction: Implications for urban development in Nigeria,' UNU-WIDER Working Paper No. 2010/43, pp. 1-18.

55. Roberts, J. (2003), 'Managing public expenditure for development results and poverty reduction.' Working Paper 203. Overseas Development Institute. [Online], [Retrieved November 15, 2013] http://www.odi.

56. org.uk/resources/download/1984.pdf Rostow, W. (1960), The stages of economic growth: a non - communist manifesto. Cambridge University Press: New York.

57. Rowan, K. (2013), Will the budget help tackle regional inequalities? Touch Stone, March 15, 2013. [Online], [Retrieved November 15, 2013] http://touchstoneblog.org.uk/ 2013/03/will-the-budget-help-tackleregional-inequalities
58. Syrquin, M. (1988), Patterns of structural change. In: Chenery HB, Srinivasan TN (eds) Handbook of development economics, Vol. 2. NorthHolland, Amsterdam, pp 197-273

59. Thornton, J. (2006), 'Fiscal decentralization and economic growth reconsidered,' Journal of Urban Economics, 61(1), 64-70.

60. Van de Walle, D. (1995), 'Public spending and the poor: What we know, what we need to know.' Policy Research Working Paper 1476. World Bank. [Online], [Retrieved November 15, 2013] http://www.

worldbank.org/external/default/WDSCont ent

Server/IW3P/IB/1995/06/01/000009265 3961019120046/Rendered/PDF/multi_pa ge.pdf

61. Vasquez, J. and Mc Nab, R. M. (2003), 'Fiscal decentralization and economic growth,' World Development, 31(9), 15971616.

62. Venables, A. J. and Kanbur, R. (2003), 'Spatial inequality and development,' Working Paper No. 2003-38, Department of Applied Economics and Management, Cornell University, Ithaca, New York, USA.

63. Williamson, J. G. (1964), 'Regional inequality and the process of national development: A description of the patterns,' Economic Development and Cultural Change, 13(4), 5-44.

64. World Bank (1994), Infrastructure for development, World Development Report, New York: Oxford University Press.

65. World Bank. (2005), East Asia decentralizes: Making local government work. Washington, D.C.: The World Bank.

66. Young, A. (2008), Endogenous TFP and cross-country income differences,' Journal of Monetary Economics, 55(6), 1158-1170. 